\title{
THE EFFECTIVENESS OF STRATEGY IN NON-PROFIT ORGANIZATIONS: AN EXPLORATORY STUDY OF ACADEMIC INSTITUTIONS
}

\author{
Elzotbek Rustambekov \\ Bryant University $\bullet$ Smithfield, Rl \\ V.K. Unni \\ Bryant University • Smithfield, Rl
}

\section{ABSTRACT}

Prior research has been relatively withdrawn to study the strategic management process in non-profit organizations, and ignored differences in strategic planning in academic institutions. In contrast, this paper argues why and how strategic planning may lead to desired levels of organizational performance in a college or university. We used mixed methodology approach based on content analysis. Our exploratory work found that higher ranked universities had strategy statement that emphasized faculty. Findings highlight the importance of a clearly articulated strategy emphasizing faculty for university ranking on the sample of 203 business schools. We provide evidence that the most successful universities are likely to proactively use and manage strategy statements for attaining higher rankings and attracting more students.

\section{INTRODUCTION}

Many strategy scholars argued that strategy is an organizational level phenomenon (Bower, 1970; Burgelman, 1983; Farjoun, 2002; Tsai, MacMillan, \& Low, 1991). As such, a clearly defined strategy and a strategic plan are viewed as the keys to a company's success (Hummelbrunner \& Jones, 2013; Jain, 1993; Mintzberg, 1994b). In fact, the importance of clear planning in strategy led to the "planning school" of strategic management, and cannot be overemphasized (Eden \& Ackermann, 2013; Mintzberg, 1994a; Mintzberg \& Lampel, 2012).

As Mintzberg (1985) wrote, strategies must be seen as an impenetrable "black box" for planning and for planners, around which, rather than inside of which, they work. Strategies may be involved in inputs to the process, support for the process, or consequences of the process. The role of planning was defined as strategic programming (Mintzberg, 1994a), where all organizations engage in formal planning, not to create strategies, but to program the strategies they already have, that is, to elaborate and operationalize their consequences formally. Planning as programming 
is clearly a systematic procedure to produce an articulated result (Mintzberg, Ahlstrand, \& Lampel, 2005; Rumelt, 1995). Planning is decision making, or more exactly a set of coordinated decision processes evoked by the dictates of strategy (Mintzberg et al., 2005). It clearly involves future thinking, and often controlling the future as well. According to Mintzberg et al., (2005) strategic programming involves a series of steps: (1) the codification of a given strategy, including its clarification and articulation; (2) the elaboration of that strategy into substrategies, ad hoc programs, and action plans of various kinds; and (3) the conversion of those substrategies, programs, and plans into routine budgets and objectives. In this paper, we analyze codification and elaboration in the sample of university strategy statements. Strategy statements, similar to mission statements, are tools that carry the essence of strategy (Carraher, Carraher, \& Mintu-Wimsatt, 2005; Cochran, David, \& Gibson, 2008).

Much of the literature on strategy emphasizes the importance of identifying the most advantageous spot an organization can occupy in the fast-moving markets with changing consumer preferences (Von Bergen \& Bressler, 2015). Recognizing the nature of strategy on the market place and considering the difference in college and university management from corporate management, for this paper we used the following definition of strategy: "a systematic way of positioning an institution with stakeholders in its environment to create value that differentiates it from competitors and leads to a sustainable advantage" (Alfred, 2006). This definition is based on four major questions related to the future of the institution and its place in the market: (1) who are the stakeholders? (2) what do those stakeholders look for and perceive as value? (3) does strategy lead to differentiation of the institution from the peer group? (4) how long can the advantage be sustained for? (Alfred, 2006).

Strategy statements can also be used as a tool for scanning (Keller, 1983). For this paper we used strategy statements that are clearly articulated statements usually two to twenty pages long. Strategy statements are different from mission statements because they are more focused on strategy, more specific and usually much longer than mission statements. Review of literature indicates that many authors have empirically explored the theory that upper-level executives particularly direct their scanning toward those environmental sectors of key importance to the organization's strategy (Hambrick, 1982; Hambrick, Humphrey, \& Gupta, 2014). The concept of scanning as used in the strategy literature includes both formal (Subramanian, Kumar, \& Yauger, 2011) and informal (Alkhafaji, 2011; Kobrin, 2013) searches, and both directed and undirected viewing (Aguilar, 1967). Strategic plans in non-profit organizations were also studied using the sample of hospitals and liberal art colleges (Hambrick, 1982) and results underlined the importance of environmental scanning for top executives. 


\section{DATA}

\section{Sample}

In order to collect the data, we approached 578 public and private universities by writing letters to administrations and checking universities' websites. Many universities had their statements of strategy (Taylor, 1984; Tegarden, Sarason, Childers, \& Hatfield, 2005) on their websites. The sample was comprised of AACSB accredited universities, partially due to the perceived higher quality of AACSB ${ }^{1}$ accredited universities and partially due to data availability (Eldredge \& Galloway, 1983; Gutierrez \& Long, 2002; Porter \& McKibbin, 1988; Pringle \& Michel, 2007). Thus these were universities that had business schools. The data we were able to collect included strategy statements from 203 AACSB accredited universities. By analyzing each report, the page length and word count of the entire report and the strategy section data was reported in an Excel file. Few universities also had an appendix relating to strategic management, which was accounted for by page length and word count. Four independent coders worked on arranging the data set and testing it for accuracy. Specifically coders were identifying strategy statements from the rest of the strategic plan, and then inputting the narrative from the strategy statements into a dedicated word document that was later used for reading by the content analysis software.

In the next step of analysis, we collected various characteristic of universities in the sample. Certain dimensions of data analysis were taken from literature and then analyzed; for instance, all universities were divided into two groups: private universities versus public universities, due to previous evidence of their differences (Ahn, Charnes, \& Cooper, 1988; Volkwein \& Parmley, 2000). Previous research has also clearly delineated other dimensions of universities, and we used those dimensions to contrast various universities. The data set was analyzed along the following dimensions that are outlined in the previous literature: (1) public universities versus private universities (Ahn et al., 1988; Volkwein \& Parmley, 2000), (2) research universities versus teaching universities (Carayol \& Matt, 2004; De Groot, McMahon, \& Volkwein, 1991; Payne, 2001), (3) religiously affiliated universities versus non-religiously affiliated universities (McConnell, 1990; Mixon, Lyon, \& Beaty, 2004; Rawwas, Swaidan, \& Al-Khatib, 2006), (4) universities with

\footnotetext{
${ }^{1}$ AACSB International-The Association to Advance Collegiate Schools of Business is a global, nonprofit membership organization of educational institutions, businesses, and other entities devoted to the advancement of management education. AACSB International advances quality management education worldwide through accreditation, thought leadership, and value-added services.
} 
countries of origin (Agasisti \& Pérez-Esparrells, 2010; Aghion, Dewatripont, Hoxby, Sapir, \& Mas-Colell, 2007; Chia \& Kang, 2014), (5) regional universities (Proctor, 2012; Trippl, Sinozic, \& Smith, 2012; Urbano \& Guerrero, 2013), (6) number of students (Ferguson, 2013; Onyeaso \& Adalikwu, 2008; Watjatrakul, 2014), (7) university's year of establishment and university's age (Universities, 2013), (8) university's ranking (Amsler \& Bolsmann, 2012; Dill \& Soo, 2005; Usher \& Savino, 2007), and (9) university's endorsement (Li-Ping Tang, Luna-Arocas, \& Whiteside, 2003).

While corporate success is often linked to profitability, for universities, which are non-profit organizations, success is often linked to high ranking (Lo, 2014; Rauhvargers, 2011). So, in the next step of analysis, the Excel file with the rankings of each university/college in our data set was created. Rankings were based on $\mathrm{QS}^{2}$, Forbes $^{3}$, U.S. News \& World Report ${ }^{4}$, Washington Monthly ${ }^{5}$, Academic Ranking of World Universities: $\mathrm{ARWU}^{6}$, and Time ${ }^{7}$.

\section{Enrollment}

The size of universities has a very broad range. The smallest university in the sample was a private university in France with only 380 students. The largest university in our sample was a large state university from United States with 98,097 students. Data in our sample suggested that larger

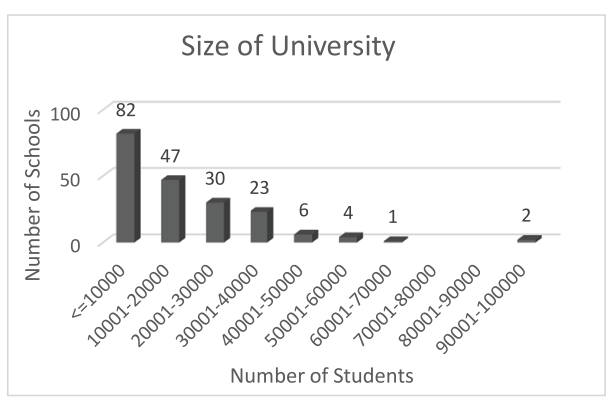
universities tend to be in the United

States where the smaller universities are generally in Europe. The average university size in the data set is roughly 17,000 students. All universities were divided into groups of 10,000 students. As seen in the graph below, the majority of universities have less than or equal to 10,000 students. The next most common university size is between 10,001 and 20,000 students. There are fewer universities with a large number of students attending. For the most part, both public and private universities have equal representation in all size categories, although the first seven smallest

\footnotetext{
${ }^{2}$ http://www.topuniversities.com/university-rankings

${ }^{3}$ http://www.forbes.com/forbes/welcome/

${ }^{4}$ http://colleges.usnews.rankingsandreviews.com/best-colleges

${ }^{5} \mathrm{http}: / /$ washingtonmonthly.com/college_guide/

${ }^{6} \mathrm{http}: / /$ www.shanghairanking.com/

${ }^{7}$ http://time.com/magazine/
} 
universities are private and the biggest university is public. Research universities are larger in size compared to teaching universities. The largest research university has 98,097 students and the smallest research university 790 . The largest teaching university has 39,256 students and the smallest has 380 students. The average size for research universities is 17,407 students and the average for teaching universities is 14,307 students.

\section{US-Based vs. International}

Although most of the universities in the data set are located in the United States, there are many international universities included. In our data set, there are 149 USbased universities and 54 international universities. The universities are from 29 countries in total. France is the second most represented country in the data set with seven universities. Canada and the United Kingdom follow closely with six universities in the data set each. The United Kingdom was also broken down into specific countries. The total of six universities of the United Kingdom can be further divided into three from

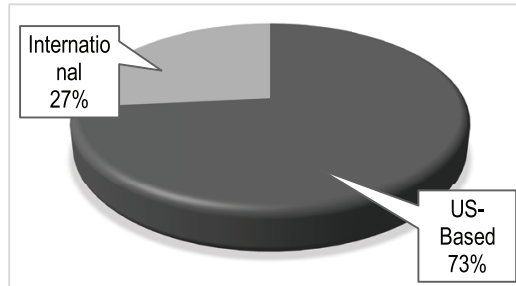

\begin{tabular}{|l|r|r|}
\hline \multicolumn{1}{|c|}{ Country } & Number & Percentage \\
\hline Canada & 6 & $3 \%$ \\
\hline United State & 149 & $73.30 \%$ \\
\hline Mexico & 3 & $1.50 \%$ \\
\hline South America & 3 & $1.50 \%$ \\
\hline Europe & 22 & $10.80 \%$ \\
\hline Middle East & 4 & $2 \%$ \\
\hline Asia & 15 & $7.40 \%$ \\
\hline Australia & 1 & $0.50 \%$ \\
\hline Total & $\mathbf{2 0 3}$ & $\mathbf{1 0 0} \%$ \\
\hline
\end{tabular}

Scotland and three from England. The international universities have a balance between public and private universities in the data set, while the majority of US-based universities in the data set are public. International universities more commonly are smaller in size where American universities tend to be larger in size. The data set shows a balance between research and teaching universities for both US-based and international universities as well.
Distribution of Schools World Wide

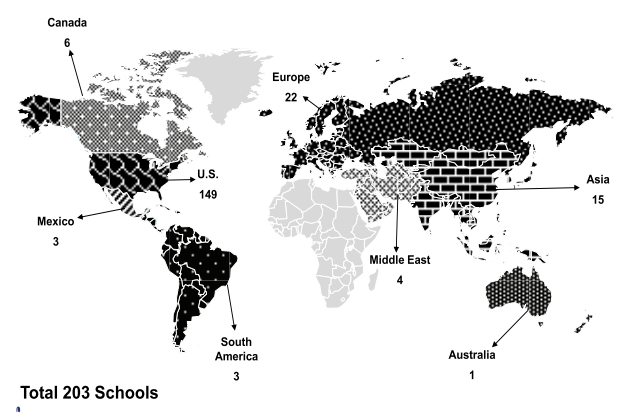




\section{Geographic Distributions}

The chart illustrates regional location of each of the 149 US-based universities. The Northeast has a total of 32 universities. Within the Northeast, 22 universities are in the Middle Atlantic and ten universities are in New England. The Midwest has 35 universities. The South has 59 universities in total. Within the South, ten universities are in the East South Central, 33 universities are in the South Atlantic, and 16 universities are in the West South Central. The West region has 23 universities, five of which are in the Mountain West and 18 in the Pacific West. Only eight of the New England universities are religiously affiliated. In the south, the majority are non-religious, public, and research-based universities. Most universities in the Midwest are public and non-religious universities. Only four universities in the West are religious and seven are private. The South, Midwest, and West all have more public universities where the Northeast has more private universities.

\section{Public vs. Private}

The university's public or private status was also accounted for. With 203 universities in total, 84 are private and 119 are public. The smallest public university in the data set is in France

\begin{tabular}{|c|c|c|c|}
\hline & Public & Private & Totals \\
\hline US-based & 95 & 54 & 149 \\
\hline International & 24 & 30 & 54 \\
\hline Totals & 119 & 84 & 203 \\
\hline
\end{tabular}
with 2,650 students, where the largest public university is in the US with 98,097 students. Only five universities that are public are also religiously affiliated. Out of the 119 public universities, 95 are US-based. Out of the 84 private universities, 24 are international. Within the 119 public universities, there is a very close balance between research universities and teaching universities.

The number of public research universities in the data set is 70 and the number of the public and teaching universities is 49 . Within the 84 private universities, there is also a very close balance between research universities and teaching universities. 
Research oriented universities account for 36 of the private universities and teaching oriented account for 48 .

\section{Research Based Universities}

Before we started the analysis, we expected teaching universities to emphasize students.

There is also a fair number of research-based universities. With 203 universities in total, 111 are research

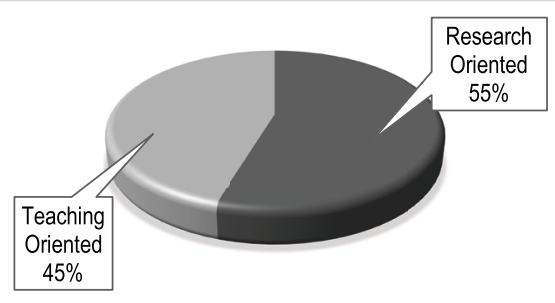
universities and 92 are not researchbased. The majority of the research universities are public universities. The research universities are mid-large sized universities as well. Research universities are typically larger, with the largest university having 98,097 students.

On the other hand, teaching universities tend to be smaller, with the smallest university being with 380 students. Most of the research universities are located in the United States. Out of

\begin{tabular}{|c|c|c|c|}
\hline & US-based & $\begin{array}{c}\text { Internati } \\
\text { onal }\end{array}$ & Totals \\
\hline Research & 80 & 31 & 111 \\
\hline Teaching & 69 & 23 & 92 \\
\hline Totals & 149 & 54 & 203 \\
\hline
\end{tabular}
the 111 research universities, 80 universities are US-based and 31 are international. Most of the teaching universities in the sample are located in the United States. Out of the 92 universities, 69 are US-based and 23 are international.

\section{Age of Universities}

The age of the universities has a very broad range in our sample. The youngest university in the sample is from Asia and it is only seven years old. The oldest university in the sample is from the UK and is 564 years old. The average age of universities in this data set is 117 years old. The first few youngest universities and the first few oldest universities are both international. In fact, most of the European universities are older. US-based universities have a broad range of ages,

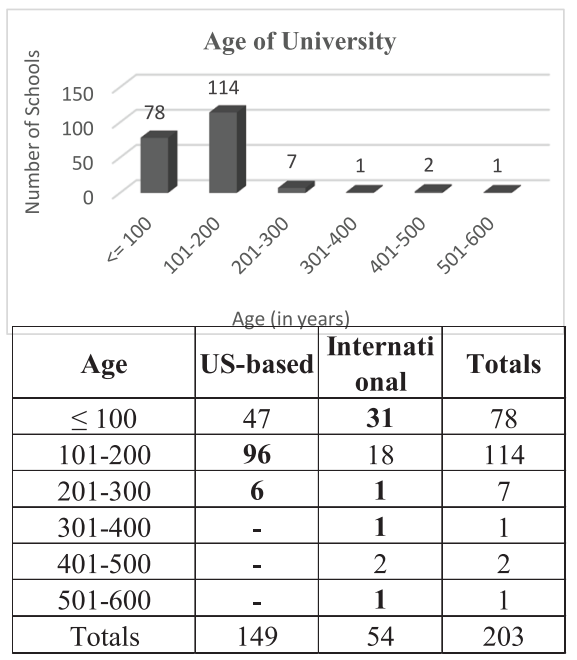


from 39 years to 248 years.

All of the US-based universities are fairly young. The international universities have a broader range of age. The oldest teaching university is 564 years old and the youngest is only seven years old. The oldest research university is 248 years old and the youngest university is 24 years old. Both research and teaching universities have an even range of ages. The average age of research universities is 112 years old where the average age of teaching universities is 117 years old.

\section{Religious vs. Non-religious}

The data set has 168 non-religious universities and 35 religiously affiliated universities. Out of the 168 non-religious universities, 114 of the universities are public. Out of the 35 religious universities, 30 of them are private.

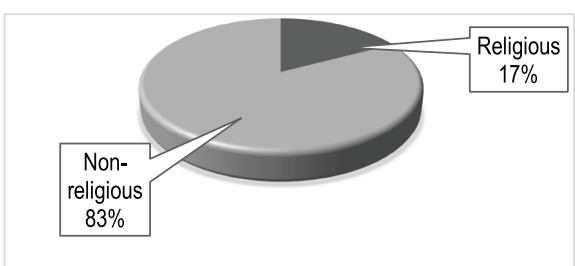

\section{ANALYSIS AND RESULTS}

US-based universities in our specific sample have a greater tendency to be public. International universities favor private universities only by a small margin. It is evident that teaching universities are smaller in size. Research universities have a wider range of size, having at least 1 university in almost every category.

With only a small number of religious universities, the most are

\begin{tabular}{|c|c|c|c|}
\hline Size & Research & $\begin{array}{c}\text { Non- } \\
\text { Research }\end{array}$ & Totals \\
\hline$\leq 10000$ & 26 & 56 & 82 \\
\hline $10001-20000$ & 30 & 17 & 47 \\
\hline $20001-30000$ & 23 & 7 & 30 \\
\hline $30001-40000$ & 16 & 7 & 23 \\
\hline $40001-50000$ & 6 & - & 6 \\
\hline $50001-60000$ & 4 & - & 4 \\
\hline $60001-70000$ & 1 & - & 1 \\
\hline $70001-80000$ & - & - & 0 \\
\hline $80001-90000$ & - & - & 0 \\
\hline $90001-10000$ & 2 & - & 2 \\
\hline Totals & 108 & 87 & 195 \\
\hline
\end{tabular}
found in the South. Each region has a significantly larger number of non-religious universities compared to religious universities.

There are more research-based universities in both the US-based and international universities categories. However, the number of teaching universities for both US-based and international universities is not too far behind. 


\section{Ranking}

As seen the graph below, many universities in the data set are regionally, nationally, and internationally ranked. With 109 universities, Forbes ranks the highest number of universities in the data set, followed by QS World with 71 universities. Each university may be ranked among a few of these measures. For example, 49 universities have only one ranking and 48 universities have two rankings. A large US-based university in the sample has six rankings. The university with six rankings is public, and 12 out of the 20 universities with five rankings are public as well. However, the universities with fewer rankings are private. Out of the 42 universities with zero rankings, 24 are private. Out of the 49 universities with one ranking, 37 of them are private.

It was a limitation of our study that we did not have any ranking that would cover all the universities in the sample, but Forbes' ranking was covering 54\% of our sample and we decided to proceed with it.

The religious universities have a wider distribution of the rankings. The university with the highest number of rankings is a US-based public university with more than 27,000 students affiliated with the Methodist Episcopal Church.

Each of the rankings uses a different approach and methodology in order to rank various universities nationally and internationally. Forbes merged with the Center for College Affordability and Productivity (CCAP) in order to establish the indicators used for determining the rankings. The two organizations decided to analyze the students' success after college rather than the success of getting into that college. When ranking 650 universities, 12 indicators were used, each one falling into one of the factors with various weights: student satisfaction $(25 \%)$, post-graduate success $(32.5 \%)$, graduation rate $(7.5 \%)$, student debt $(25 \%)$, and academic success (10\%).

As part of our analysis, we plotted endowment versus ranking. The results clearly indicated that higher ranked universities have much larger endowments. 
Interestingly, there were few outliers of universities with lower ranking that had endowments larger than many universities that were ranked higher. These outliers prove the general concept of positive correlation between the university's ranking and endowment size.

\section{Content Analysis}

For the content analysis part of this paper, we used NVivo 10 software. All of the strategy statements were imported into the NVivo Program. We created one data set that contained the structured arrangement of 203 strategy statements and various characteristics of universities, including rankings. In the next step, we opened and explored the strategy statements, coding and making a number of nodes to collect all the relevant data. Thirty text search queries were performed, and query results were gathered in various nodes. The NVivo 10 permits several types of searches, ranging from exact to similar. Below are the NVivo results for various searches. Each term was searched three times, using the exact word (marked Exact), half way through the similarity scale (marked Middle) and all the way through similarity scale (marked Similar). The term "planning" was the most common, with 217,453 references in 202 out of 203 strategy statements. Surprisingly, "strategic development" was only cited 65 times in 20 out of 203 strategy statements.

Considering the importance of sustainability, a number of searches on "sustainability" related terms were performed. "Social responsibility" was the most common term related to sustainability and was present in every strategy statement with 248,521 references. "Corporate Social Responsibility" and its abbreviated form "CSR" were among the least referenced terms appearing in 69 and 26 strategy statements respectively. "Sustainability" term was present in every strategy statement and yielded

\begin{tabular}{|c|c|c|}
\hline 1. Name & B Sources & References \\
\hline$\square$ Strategy & 0 & 0 \\
\hline Planning (Similar) & 202 & 217453 \\
\hline Planning (Middle) & 202 & 91880 \\
\hline Strategy (Similar) & 195 & 7776 \\
\hline Strategy (Middle) & 195 & 7169 \\
\hline Planning (Exact) & 199 & 4781 \\
\hline Strategy (Exact) & 183 & 4325 \\
\hline Strategic Planning (Exact) & 178 & 1643 \\
\hline Strategic Planning (Similar) & 178 & 1643 \\
\hline Strategic Development (Exact) & 20 & 65 \\
\hline Strategic Development (Similar) & 20 & 65 \\
\hline$\boxminus \bigcirc$ Sustainability & 0 & 0 \\
\hline Social Responsibility (Similar) & 203 & 248521 \\
\hline Sustainability (Similar) & 203 & 108298 \\
\hline Sustainability (Medium) & 200 & 30899 \\
\hline Social Responsibility (Middle) & 194 & 17425 \\
\hline Green (Similar) & 190 & 10404 \\
\hline Social Responsibility (Exact) & 186 & 7287 \\
\hline Green (Middle) & 180 & 5627 \\
\hline Sustainability (Exact) & 120 & 779 \\
\hline Green (Exact) & 71 & 301 \\
\hline Corporate Social Responsibility (Similar) & 69 & 282 \\
\hline Corporate Social Responsibility (Exact) & 69 & 282 \\
\hline $\operatorname{CSR}$ (Exact) & 26 & 122 \\
\hline CSR (Similar) & 26 & 122 \\
\hline
\end{tabular}
108,298 references.

We visualized our data and performed a word frequency query. The word frequency algorithm scans the documents and identifies most frequently used words. 
An interesting finding was that better ranked universities were much more faculty focused in their strategy statements, while their lower ranked counterparts were more focused on students and other aspects of strategy (Please see the word cloud showing the effect).
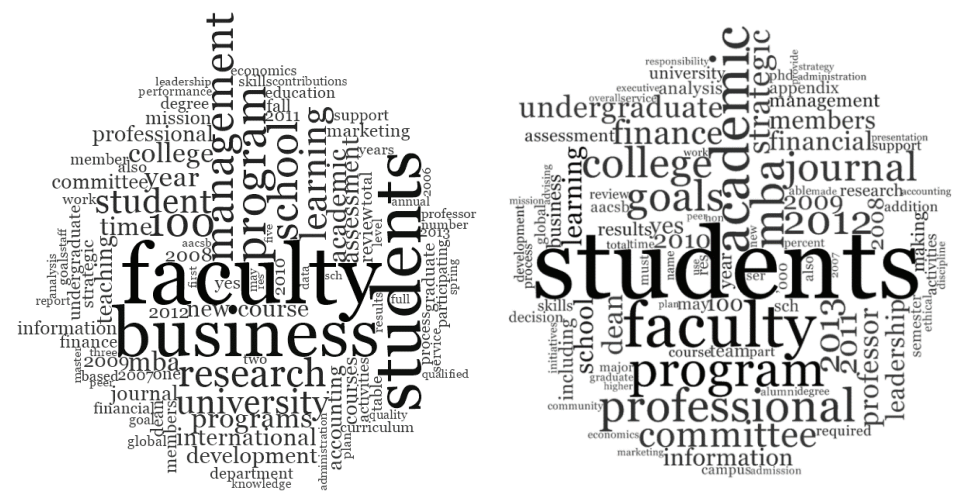

Towards the end of the analysis, we performed searches in seemingly unrelated terms like facilities and buildings. To our surprise,

\begin{tabular}{|c|c|c|c|}
\hline 1. Name & & B Sources & References \\
\hline$\square \mathrm{O}$ Other Di & & 0 & 0 \\
\hline 0 Build & t) & 66 & 133 \\
\hline Buildi & dle) & 201 & 23102 \\
\hline Buildi & ilar) & 203 & 266250 \\
\hline Facili & & 146 & 1003 \\
\hline Facili & (dle) & 177 & 2298 \\
\hline$\bigcirc$ Facili & ilar) & 201 & 95302 \\
\hline
\end{tabular}
every strategy statement contained the term buildings and the total number of references was 266,250. This may be an indication that in today's infrastructure driven world, physical aspects of universities play a greater role, and universities use the term to indicate investments into infrastructure or development of buildings as one of the signs of strategic development and strategic growth.

\section{CONCLUSIONS}

Academic strategy touches many aspects of universities including (1) academic strength and weaknesses, (2) financial strength and weaknesses, (3) the competitive situation, (4) market preferences and several other (Keller, 1983). To elicit academic strategy we used strategy statements. Strategy statements are used as an important guiding tool for both companies and non-profit organizations. In this study, we analyzed 203 strategy statements from universities across the world. Our data included private and public, research-oriented and teaching-oriented, religiously-affiliated and non-religiously affiliated, small and large, highly ranked 
and non-highly ranked universities. We employed mixed methods and applied content analysis to enhance the discussion on the importance of analyzing strategy statements and using mixed methods in today's business research.

Our findings indicate that strategy statements that talk more about "faculty" were associated with universities that were higher ranked by Forbes, while statements that talked more about "students" were associated with universities that had lower rankings. We also established that higher rankings of universities were associated with larger university endowments. This may indicate that universities seeking larger endowments need to emphasize the "faculty" dimension in their strategy statements. A possible explanation of the relationship can be that universities that emphasize "faculty" have more programs geared towards faculty development and attract higher quality faculty, which results in higher quality students attracted to the classroom, turning into more successful alumni and bringing a higher number of university endowment.

This paper provides evidence that there is a relationship between strategy statements and performance, as measured by university ranking or university endowment. For universities, performance is associated with ranking, and our analysis indicated that ranking was highly correlated with university endowment. Further analysis indicated that better ranked universities have longer strategy statements that concentrate more on faculty while lower ranked universities had shorter strategy statements that emphasized "students." A number of other tests and correlations were performed, including universities' age, location, religious affiliation, number of enrolled students and various rankings.

In managerial terms, our study indicates that explicit strategy statements do matter, and managers and administrators of different ranks need to put time and effort to have well written strategy statements that all stakeholders of an organization can refer to. This paper is also written to start a discourse on the importance of strategy statements and on usage of different methods of analysis for evaluating the effectiveness of strategy statements, and needless to say that our paper is an attempt and more needs to be done in the area. 


\section{APPENDIX}

\section{Graph 1. Management in Higher Education}

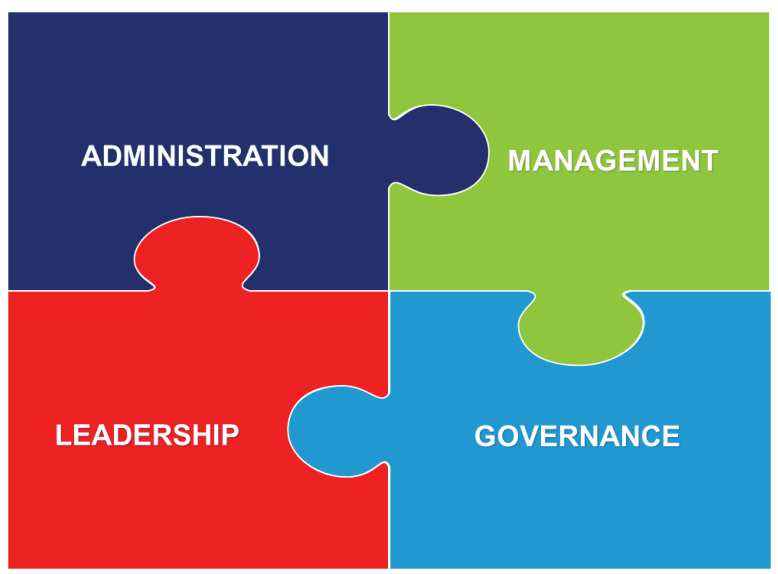

'Academic Strategy: The Management Revolution in American Higher Education' by George Keller, page 122-126.

\section{Graph 2. Forming an Academic Strategy}

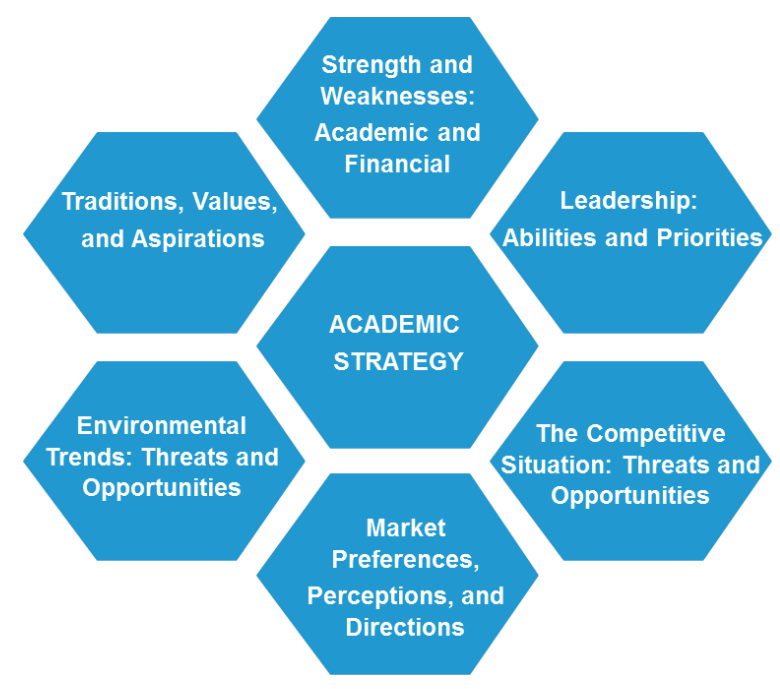

'Academic Strategy: The Management Revolution in American Higher Education' by George Keller, page 152. 
Appendix 3. Content Analysis.

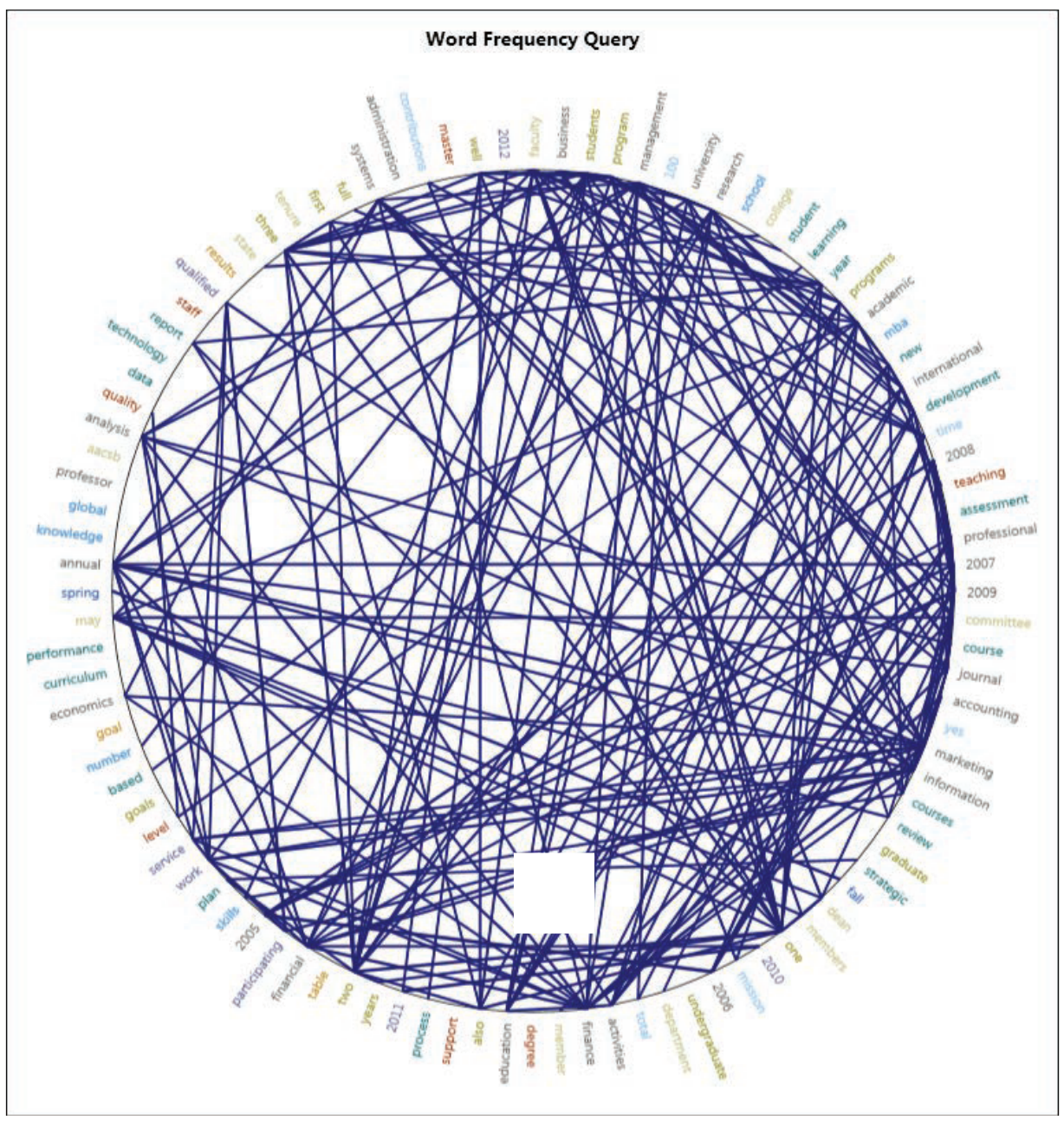

\section{REFERENCES}

Agasisti, T. and Pérez-Esparrells, C. (2010). Comparing efficiency in a cross-country perspective: the case of Italian and Spanish state universities. Higher Education, 59(1), 85-103.

Aghion, P., Dewatripont, M., Hoxby, C., Sapir, A., \& Mas-Colell, A. (2007). Why reform Europe's universities?

Aguilar, F. J. (1967). Scanning the business environment: Macmillan. 
Ahn, T., Charnes, A., \& Cooper, W. W. (1988). Some statistical and DEA evaluations of relative efficiencies of public and private institutions of higher learning. Socio-Economic Planning Sciences, 22(6), 259-269.

Alfred, R. L. (2006). Managing the big picture in colleges and universities.

Alkhafaji, A. F. (2011). Strategic management: formulation, implementation, and control in a dynamic environment. Development and Learning in Organizations: An International Journal, 25(2).

Amsler, S. S. and Bolsmann, C. (2012). University ranking as social exclusion. British journal of sociology of education, 33(2), 283-301.

Bower, G. H. (1970). Imagery as a relational organizer in associative learning. Journal of Verbal Learning and Verbal Behavior, 9(5), 529-533.

Burgelman, R. A. (1983). A process model of internal corporate venturing in the diversified major firm. Administrative Science Quarterly, 223-244.

Carayol, N. and Matt, M. (2004). Does research organization influence academic production?: Laboratory level evidence from a large European university. Research Policy, 33(8), 1081-1102.

Carraher, S. M., Carraher, S. C., \& Mintu-Wimsatt, A. (2005). Customer service management in Western and Central Europe: A concurrent validation strategy in entrepreneurial financial information services organizations. Journal of Business Strategies, 22(1), 41.

Chia, J. and Kang, C. (2014). Where Are My Country (wo) men? The Lack of Singaporean Academics in Singapore's Universities.

Cochran, D. S., David, F. R., \& Gibson, C. K. (2008). A framework for developing an effective mission statement. Journal of Business Strategies, 25(2), 27.

De Groot, H., McMahon, W. W., \& Volkwein, J. F. (1991). The cost structure of American research universities. The Review of Economics and Statistics, 424431.

Dill, D. D. and Soo, M. (2005). Academic quality, league tables, and public policy: A cross-national analysis of university ranking systems. Higher Education, 49(4), 495-533.

Eden, C. and Ackermann, F. (2013). Making strategy: The journey of strategic management: Sage.

Eldredge, D. L., \& Galloway, R. F. (1983). Study of the undergraduate business policy course at AACSB-accredited universities. Strategic Management Journal, 4(1), 85-90.

Farjoun, M. (2002). Towards an organic perspective on strategy. Strategic Management Journal, 23(7), 561-594. 
Ferguson, L. (2013). Student life-Staying the course: Universities are taking action to reduce the number of students who leave nurse training, says Linda Ferguson. Nursing Standard, 27(29), 64-64.

Gutierrez, C. F. and Long, N. M. (2002). Web Site accessibility of AACSB-accredited universities: Meeting the requirements of the law (s). Journal of Educational Technology Systems, 30(1), 69-84.

Hambrick, D. C. (1982). Environmental scanning and organizational strategy. Strategic Management Journal, 3(2), 159-174.

Hambrick, D. C., Humphrey, S. E., \& Gupta, A. (2014). Structural interdependence within top management teams: A key moderator of upper echelons predictions. Strategic Management Journal.

Hummelbrunner, R. and Jones, H. (2013). A guide for planning and strategy development in the face of complexity. Background Note, Overseas Development Institute, London.

Jain, S. C. (1993). Marketing planning and strategy: Cincinnati South-Western Publishing Company 1985.

Keller, G. (1983). Academic strategy: The management revolution in American higher education: JHU Press.

Kobrin, S. (2013). Strategic integration in fragmented environments: Social and political assessment by subsidiaries of multinational firms. Paper presented at the Strategies in Global Competition: Selected Papers from the Prince Bertil Symposium at the Institute of International Business.

Li-Ping Tang, T., Luna-Arocas, R., \& Whiteside, H. D. (2003). Money ethic endorsement, self-reported income, and life satisfaction: University faculty in the US and Spain. Personnel Review, 32(6), 756-773.

Lo, W. Y. W. (2014). Introduction University Rankings (pp. 1-14): Springer.

McConnell, M. W. (1990). Academic freedom in religious colleges and universities. Law and Contemporary Problems, 303-324.

Mintzberg, H. (1994a). Rise and fall of strategic planning: Simon and Schuster.

Mintzberg, H. (1994b). The rise and fall of strategic planning: Reconceiving roles for planning, plans, planners (Vol. 458): Free Press New York.

Mintzberg, H., Ahlstrand, B., \& Lampel, J. (2005). Strategy Safari: A Guided Tour Through The Wilds of Strategic Mangament: Simon and Schuster.

Mintzberg, H. and Lampel, J. (2012). Reflecting on the strategy process. Sloan Management.

Mintzberg, H. and McHugh, A. (1985). Strategy Formation in an Adhocracy. Administrative Science Quarterly, 30(2), 160-197. 
Mixon, S. L., Lyon, L., \& Beaty, M. D. (2004). Secularization and national universities: The effect of religious identity on academic reputation. The Journal of Higher Education, 75(4), 400-419.

Onyeaso, G. and Adalikwu, C. (2008). An empirical test of customer retentionperceived quality link: strategic management implications. Journal of Business Strategies, 25(1), 53.

Payne, A. A. (2001). Measuring the effect of federal research funding on private donations at research universities: is federal research funding more than a substitute for private donations? International Tax and Public Finance, 8(5-6), 731-751.

Porter, L. W. and McKibbin, L. E. (1988). Management Education and Development: Drift or Thrust into the 21st Century? : ERIC.

Pringle, C. and Michel, M. (2007). Assessment practices in AACSB-accredited business schools. Journal of Education for Business, 82(4), 202-211.

Proctor, C. (2012). Understanding Faculty Donors: Giving at Historically Black Colleges and Universities in the Southern Region of the United States. University of Central Florida Orlando, Florida.

Rauhvargers, A. (2011). \{Global university rankings and their impact\}. Leadership for WorldClass Universities Challenges for Developing Countries(June).

Rawwas, M. Y., Swaidan, Z., \& Al-Khatib, J. (2006). Does religion matter? A comparison study of the ethical beliefs of marketing students of religious and secular universities in Japan. Journal of Business Ethics, 65(1), 69-86.

Rumelt, R. P. (1995). Inertia and transformation Resource-based and evolutionary theories of the firm: Towards a synthesis (pp. 101-132): Springer.

Subramanian, R., Kumar, K., \& Yauger, C. (2011). The scanning of task environments in hospitals: An empirical study. Journal of Applied Business Research (JABR), 10(4), 104-115.

Taylor, S. (1984). Making bureaucracies think: the environmental impact statement strategy of administrative reform: Stanford University Press.

Tegarden, L. F., Sarason, Y., Childers, J. S., \& Hatfield, D. E. (2005). The engagement of employees in the strategy process and firm performance: The role of strategic goals and environment. Journal of Business Strategies, 22(2), 75.

Trippl, M., Sinozic, T., \& Smith, H. L. (2012). The "third mission" of universities and the region: comparing the UK, Sweden and Austria. Paper presented at the 52nd European Congress of the RSAI, Bratislava. 
Tsai, W. M.-H., MacMillan, I. C., \& Low, M. B. (1991). Effects of strategy and environment on corporate venture success in industrial markets. Journal of business venturing, 6(1), 9-28.

Universities, U. (2013). Patterns and trends in UK higher education 2013.

Urbano, D., \& Guerrero, M. (2013). Entrepreneurial universities socioeconomic impacts of academic entrepreneurship in a European region. Economic Development Quarterly, 27(1), 40-55.

Usher, A. and Savino, M. (2007). A global survey of university ranking and league tables. Higher Education in Europe, 32(1), 5-15.

Volkwein, J. F. and Parmley, K. (2000). Comparing administrative satisfaction in public and private universities. Research in Higher Education, 41(1), 95-116.

Von Bergen, C. and Bressler, M. S. (2015). Active Waiting As Business Strategy:

Learning From The Serengeti Plains. Journal of Business Strategies, 32(1).

Watjatrakul, B. (2014). Factors affecting students' intentions to study at universities adopting the "student-as-customer" concept. International Journal of Educational Management, 28(6), 676-693.

\section{BIOGRAPHICAL SKETCH OF AUTHORS}

Elzotbek Rustambekov, Ph.D., is Assistant Professor of Strategic Management and International Business, at Bryant University, RI. He is originally from Uzbekistan. Prior to career in academia Dr. Rustambekov worked with the Ministry of Finance of Uzbekistan, Tashkent City Hall, Organization for Security and Cooperation in Europe (OSCE) and United Nations Development Program (UNDP). Dr. Rustambekov holds an MBA from Hofstra University, an MSc from the University of St Andrews, and a PhD from Old Dominion University.

V.K. Unni, D.B.A., is former Dean of the College of Business and Distinguished Professor of Business at Bryant University, RI. He was also Vice President for Academic Affairs at Bryant University for 13 years. Dr. Unni is an elected fellow of the U.S Association for Small Business and Entrepreneurship and also served as their President. He received his doctoral degree in Management from Louisiana Tech University and has spent more than 30 years in the university environment as faculty and as an academic administrator. 